\title{
Research on the Current Situation and Countermeasures of Sports Engineering for Colleges and Universities in China
}

\author{
Jianxin $\mathrm{Gao}^{1 *}$, Liya $\mathrm{Li}^{1}$, Yuan $\mathrm{Shu}^{1}$ \\ ${ }^{1}$ Department of sports, Jiangxi Teachers College, Yingtan, Jiangxi, 335000, China
}

\begin{abstract}
The construction and development of sports engineering subject is based on its special subject knowledge system and structure. Based on the analysis of the research field of sports engineering, this paper analyzes and constructs the knowledge system of sports engineering from many aspects of basic theory, such as methodology, engineering application and technical system. The discipline construction of sports engineering is a process of continuous improvement from knowledge to organization. The three main factors affecting its development are discipline knowledge, discipline organization and discipline soft, hard environment. Taking these three factors as the first level indicators and combining with the characteristics of the development of sports engineering discipline in China's universities, this study designs an indicator system for the feasibility evaluation of the construction of sports engineering discipline in universities, and puts forward countermeasures and suggestions for the development of sports engineering discipline in China.
\end{abstract}

\section{Introduction}

At the end of the 20th century, great changes have taken place in the international academic situation, and a large number of new disciplines have emerged in the world. In the development of new subject research, a group of high-level researchers with different subject backgrounds have formed an interdisciplinary research team with high professional level, novel knowledge structure and comprehensive disciplines. These teams aim to attack new research fields and expand a large number of new disciplines with great development value. This has brought greater challenges to the discipline construction of colleges and universities, but also brought opportunities for rapid development [1].

The emergence of sports engineering, as mentioned before, conforms to the needs of social economy and scientific and technological development, and is the inevitable integration of knowledge. Sports engineering, as an important support for discipline construction and personnel training, is restricted by different development environment of colleges and universities while following the general rules of discipline construction and development. At present, this subject is booming in the world, but it is still in its infancy in China. Although not all colleges and universities have the ability and conditions to construct this subject, it has a bright and broad prospect [2].

\section{The research significance of sports engineering}

\subsection{Promote the transformation of national sports technology and policy}

The competition between the world sports competitions is actually the competition between sports science and technology, and the competition of sports science and technology is the competition of the strength of science and technology between countries. Although China is known as a world sports power, it is realized by the strategy of "gold medal". High level sports are relatively concentrated, and the mass base is relatively weak. The development of sports science and technology in foreign countries pays attention to the cooperation with colleges and universities, high-level sports engineering scientific research and high-quality personnel training engaged in sports industry is stable and orderly growing [3]. Therefore, through the research on the subject construction of sports engineering in colleges and universities, combining the subject knowledge advantages of colleges and universities with the development of sports science and technology will provide a new way for the development of sports science and technology in China, and lay a foundation for the policy transformation from "gold medal sports" to mass sports in China.

*Corresponding author's email: gaojianxin1985@126.com 


\subsection{Subject reference development}

In foreign countries, especially in Britain, Japan and other countries with better development of sports industry, there are relatively rich research results of sports engineering, forming a relatively mature discipline system. Their discipline development mode will provide a good reference for the development of sports engineering discipline in China. Through the exploration and comparison of the discipline construction of Sports Engineering at home and abroad, it is helpful to understand the differences between the discipline and specialty setting of sports engineering in China and the more mature countries in the world and the problems existing in the discipline setting of sports engineering, to shorten the gap between the discipline and the advanced countries, and to find the development path suitable for the national conditions of China [4].

\subsection{Exploring the development path of new interdisciplinary}

Sports engineering is a new interdisciplinary subject in the world. Under the premise of following the law, this study will analyze the particularity of the college of physical education engineering, and put forward the general strategy and path for the development of the discipline of physical education engineering in colleges and universities, so as to build the discipline of sports engineering suitable for colleges and universities. Because of the typicality of the discipline nature of sports engineering, it can provide reference for how to cultivate new interdisciplinary subjects in the process of discipline development in colleges and universities [5].

\section{The concept of sports engineering}

As a new subject, sports engineering is difficult to define accurately. Aleksandr Subic, of the Royal Melbourne University of technology, Australia, believes that sports engineering is a new discipline. He believes that sports engineering is an interdisciplinary and comprehensive discipline formed by combining sports science and engineering science. Its remarkable feature is that engineering technology is an applied research in the sports equipment and its performance test in sports [6]. In addition, Steve Haake, one of the founders of sports engineering, believes that sports engineering is a new discipline that applies traditional engineering disciplines and technical knowledge to the research of sports equipment, promotes and improves the sports level of sports participants, reduces sports injuries and promotes the healthy development of competitive sports. He believes that sports engineering is closely related to sports science, but different from sports science which pays more attention to the analysis and research of athletes' sports level [7]. Thirdly, according to its research content and scope, as well as the analysis of its nature, sports engineering is basically equivalent to the concept of "sports equipment engineering" in China. The domestic sports engineering scholars describe the research scope of sports engineering, and think that sports engineering is the organic combination of engineering and sports science. The research scope involves the interdisciplinary fields such as hydrodynamics, mechanical engineering, material engineering biomechanics.

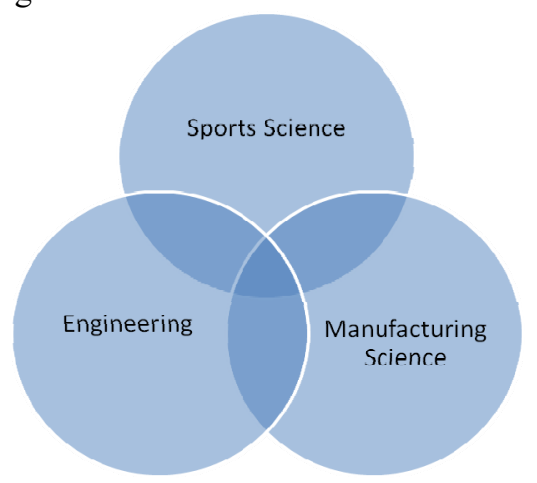

Fig.1. The related fields of sports engineering

\section{The current situation of sports engineering discipline for colleges and universities}

\subsection{The current situation of sports engineering in colleges and universities}

Wuhan Sports University, Shenyang University of Technology and Liaocheng University, Shanghai Sports University and Beijing Sports University, the domestic universities offer undergraduate programs in sports engineering [8]. These colleges and universities not only have professors, researchers, senior engineers, postdoctoral and other scientific research and teaching personnel, but also a group of national coaches, international referees and experts in scientific research, teaching and training who are engaged in sports, competitive gymnastics, martial arts, and other sports etc [9]. Many of them have served as head coach, coach and research coach in the national team. It is because of these multi-disciplinary talents that these institutions can achieve fruitful results in the research of multidisciplinary edge and cross field. In addition, there are many laboratories in Sports Engineering Research Institutes of these colleges: digital simulation laboratory, electronic and sensor laboratory, mechanical foundation laboratory, strength quality testing laboratory, humanmachine engineering laboratory, etc [10].

Table. 1. Opening situation of sports engineering major for domestic colleges and universities in China

\begin{tabular}{ccccc}
\hline & Time & support & Level & Features \\
\hline $\begin{array}{c}\text { Shenyang } \\
\text { Universitv of }\end{array}$ & 2005 & $\begin{array}{c}\text { Mechanical } \\
\text { Lahoratorv }\end{array}$ & Bachelor & $\begin{array}{c}\text { Electromechani- } \\
\text { cal }\end{array}$
\end{tabular}




\begin{tabular}{|c|c|c|c|c|}
\hline $\begin{array}{c}\text { Wuhan } \\
\text { Sport Universitv }\end{array}$ & 2008 & $\begin{array}{l}\text { National Sports } \\
\text { Laboratory }\end{array}$ & $\begin{array}{l}\text { Bachelor / } \\
\text { Graduate / }\end{array}$ & Water Sports \\
\hline $\begin{array}{l}\text { Liaocheng } \\
\text { universitv }\end{array}$ & 2008 & $\begin{array}{l}\text { Equipment } \\
\text { Engineering }\end{array}$ & Bachelor & $\begin{array}{l}\text { Machinery, } \\
\text { Materials }\end{array}$ \\
\hline $\begin{array}{c}\text { Shanghai Sport } \\
\text { University }\end{array}$ & 2013 & $\begin{array}{c}\text { Sports Biology } \\
\text { Laboratory }\end{array}$ & graduate / doctor & $\begin{array}{c}\text { Sports } \\
\text { Biomechanics }\end{array}$ \\
\hline $\begin{array}{c}\text { Beijing Sport } \\
\text { University }\end{array}$ & 2018 & $\begin{array}{l}\text { College of Sports } \\
\text { Engineering }\end{array}$ & $\begin{array}{l}\text { Bachelor / } \\
\text { Graduate / }\end{array}$ & $\begin{array}{l}\text { Sports Artificial } \\
\text { Intelligence }\end{array}$ \\
\hline
\end{tabular}

Table.2. Curriculum situation of sports engineering for domestic colleges and universities in China

\begin{tabular}{|c|c|}
\hline Module & $\begin{array}{c}\text { Sports Engineering Related Courses } \\
\end{array}$ \\
\hline Basic Course & $\begin{array}{c}\text { Advanced mathematics, Linear algebra, Probability and statistics, Physics, } \\
\text { Biomechanics, Mechanical and material science, Introduction to sports } \\
\text { engineering, Sports equipment science, Anatomy, Physiology, Ergonomics, } \\
\text { Manufacturing }\end{array}$ \\
\hline Major Core Courses & $\begin{array}{c}\text { Mechanical design, Electronic and electrical engineering, Sports medicine, } \\
\text { Ball technology and foundation, Sports training }\end{array}$ \\
\hline Elective Course & $\begin{array}{c}\text { Material physics, Material processing, System simulation, CAD design, } \\
\text { Computer aid, Application of competitive sports }\end{array}$ \\
\hline $\begin{array}{l}\text { Professional } \\
\text { Improvement } \\
\text { Course }\end{array}$ & $\begin{array}{l}\text { Computer linguistics, Foreign language of science and technology, Fluid } \\
\text { mechanics, Principles of microcomputer and single chip microcomputer, } \\
\text { Mechanical engineering, Artificial intelligence science }\end{array}$ \\
\hline
\end{tabular}

\subsection{Professional construction and knowledge system of sports engineering}

At present, colleges and universities have initially formed a representative subject knowledge system of sports engineering. Next, according to the subordinate relationship of subject knowledge in the subject classification system, the structure of the subject knowledge system of sports engineering in colleges and universities is integrated and classified. From the point of view of the interdisciplinary academic knowledge needs of the sports equipment engineering professionals in various schools in China, it is found that the current discipline system of sports engineering in colleges and universities in China mainly includes mechanical engineering, electronic and electrical engineering, sports and other disciplines. The research direction of sports engineering in China mainly focuses on the research of the hydrodynamic performance of sports equipment, the testing equipment and development of visual intelligent training, the monitoring and evaluation of strength quality and sports technology and sports electronic information engineering; the direction of sports materials.

\section{Conclusions}

This paper aims to analyze the sports engineering subject in colleges and universities, so the conclusions are as follows:

(1) Sports engineering is a new cross applied subject. Sports engineering can cover multi-disciplinary knowledge such as sports science and engineering. In the early stage of the development of new disciplines, in order to further promote the prosperity of disciplines, we can break the limitation of traditional disciplines, and do not make a clear positioning of disciplines. The construction of sports engineering discipline in colleges and universities has a broad prospect in China.

(2) The discipline construction of sports engineering should follow the general laws of discipline construction, especially the development laws of interdisciplinary, emerging disciplines and applied disciplines, take green sports and stand up to nature as the concept of discipline development, take comprehensively promoting human development, following the laws of scientific research and meeting the high-level social needs as the development logic.

(3) The construction of sports engineering discipline is based on the framework and optimization of discipline knowledge system, while its knowledge system is based on its research field. On the basis of synthesizing the knowledge of this subject in colleges and universities at home and abroad, this paper constructs and optimizes the knowledge system of sports engineering subject from four aspects: basic theory, methodology, engineering application and technical system. The discipline construction of sports engineering is a cycle from knowledge to organization.

\section{Acknowledgement}

This research was financially supported by the (1) Science and Technology Research Project of Jiangxi Education Department in China (Grant NO.GJJ161329) (2)Humanities and Social Sciences Planning Project of Colleges and Universities for Jiangxi Province in China (Grant NO.TY18126, TY19110). 


\section{References}

1. Xu Bihong. Research on the discipline construction of physical education engineering in Chinese universities [D]. China University of mining and technology, 2012

2. Yu Daifeng. Research progress, problems and Countermeasures of Sports Engineering in China from 2000 to 2014 [C]. China Sports Science Society. Summary of papers of the 10th National Sports Science Conference in 2015 (2). China Sports Science Society: China Sports Science Society, 2015: 937-939

3. Wang Leilei. Research on theoretical system construction and development strategy of sports engineering discipline in China [D]. Beijing Sport University, 2016

4. Qu Ping, Zheng Weitao, Shi Qing, he Haifeng, Ma Yong. Current situation and Prospect of application of Sports Engineering in sports medicine [J]. Journal of Wuhan Institute of physical education, 2010,44 (02): 76-80

5. Liu Zhirong. Analysis of the current situation of wearable testing system in ice and snow sports [C]. Sports biomechanics branch of Chinese Academy of Sports Sciences. Summary of papers of the 20th National Sports Biomechanics academic exchange conference. Sports biomechanics branch of Chinese Academy of Sports Sciences: Sports Biomechanics branch of Chinese Academy of Sports Sciences, 2018:71-72

6. Jianxin Gao. The Construction of School Sports Security System and the Management for Operation Control in China[C]. Nanyang University of technology, Hong Kong Global Research Association, 2018: 603-608

7. Liu Hejun. Applied research in materials and physical engineering construction in Colleges and universities [J]. Bonding, 2019,40 (08): 73-75

8. Biotechnology - Biomedical Engineering; New Findings from Roma Tre University Describe Advances in Biomedical Engineering (A Novel Technique to Design and Optimize Performances of Custom Load Cells for Sport Gesture Analysis)[J]. Biotech Week,2019.

9. Zheng Weitao. Science and technology of Sports Engineering of Wuhan Institute of physical education to support the Olympic Games [C]. Chinese Academy of Sports Sciences. Summary of papers of the 11th National Congress of Sports Sciences. Chinese Academy of Sports Sciences: Chinese Academy of Sports Sciences, 2019:247-249

10. Liu Hejun. Applied research in materials and physical engineering construction in Colleges and universities [J]. Bonding, 2019,40 (08): 73-75 